International Journal of Child, Youth and Family Studies (2016) 7(1): 148-170

\title{
SMUDGE THIS: ASSIMILATION, STATE-FAVOURED COMMUNITIES AND THE DENIAL OF INDIGENOUS SPIRITUAL LIVES
}

\section{Vanessa Watts}

\begin{abstract}
This paper will examine how the transformation of Indigenous places has interrupted the inheriting processes of Indigenous communities. The primary contention of this inquiry is that the spirit world for Anishnaabeg is place-based. Amidst colonialism and the introduction of Christianity during contact, the spiritual lives of humans, nonhumans, and therefore place were damaged. The ability of we Indigenous peoples to inherit elements of our cosmologies amidst these transformed, industrialized places has also been compromised. Issues of material, spatial, and spiritual disembodiment as related to localized, ceremonial practices will be explored. Specifically, meaningful ceremony versus "boardroom smudging" will be examined as it relates to the assimilationist agenda of the state.
\end{abstract}

Keywords: spirituality, materiality, place, locatable knowledges

Vanessa Watts, MA is a full-time lecturer in the Indigenous Studies program at McMaster University, Hamilton Hall Room 103/F, McMaster University, Hamilton , ON L8S 4L8. E-mail: wattsv@mcmaster.ca 
The survival of Indigenous peoples and our traditional practices is generally measured on a scale of demise versus adaptability (Vizenor, 2008). Regarded historically as a doomed race, it is still surprising to many that we continue to exist at all. The quandary of this circumstance is usually resolved in the demonstrated ability of Indigenous peoples to adapt. Adapting to the ongoing theft of our lands, continuing to practise our traditional ceremonies despite intense missionizing operations throughout our territories, and so forth. This politics of adaptability are reminiscent of Coulthard's (2007) politics of recognition - the reconciling of Indigenous peoples to the settler state's processes of domination. This paper will interrogate how Anishnaabe ${ }^{1}$ spiritual practices have been abstracted and evacuated from place in a continued effort towards the assimilation of Indigenous communities. I will undertake this examination in two lines of inquiry.

Firstly, the spiritual violations present in the Indian Residential School (IRS) system will be discussed and framed as a method of inscribing a new, assimilated identity onto Indigenous children. I argue that displaced forms of Christianity that were central to the British colonial project and perpetuated colonialism through making universalist claims are incommensurate with place-based Anishnaabe spirituality. The attempted disembodiment of place from its spiritual life through forced Christianization contributes to a denial of Indigenous ceremony, thereby interrupting the process of inheriting. In turn, this dislocation has fostered an environment wherein the politics of adaptability (assimilation) are intensified. As Canada attempts to transition to a less explicitly violent relationship with Indigenous peoples, the Indigenous ceremonial practices that were once proscribed during the IRS era are currently not only allowable, but engaged with.

Thus, my second line of inquiry will address more contemporary functions of Indigenous ceremony as they relate to assimilationist goals of the state. I explore the effectiveness of Anishnaabe ceremonial life amidst colonized places, specifically in industrialized, urban communities. This discussion problematizes the assumption that our process of inheriting is amenable to the challenges produced by colonialism, thereby resulting in so-called reconciled communities.

My contention is that residential schools and urban centres are significant material fabrications of colonialism, both of which accelerate an assimilationist agenda, and both of which are actively produced in contravention of Indigenous spiritual relationships. The inheriting

\footnotetext{
1 The Anishnaabe are one of the largest nations in North America. Anishnaabe homelands include territories in the provinces of Ontario, Manitoba, and Saskatchewan, as well as in the American states of Michigan, Wisconsin, and Minnesota. The Anishnaabe include the Ojibway, Algonquin, Odawa, Chippewa, and Saulteaux peoples (see Minnesota Historical Society, 1973).
} 
of transformed, colonial places interrupts our ability as Anishnaabeg ${ }^{2}$ not only to communicate with all aspects of community (including the spirit world), but may actually transform our spirit world. It is therefore necessary to trace how Anishnaabe spirituality is understood, and how it is subsequently considered both deniable and welcome by the state.

\section{Place and Inheritance in Anishnaabe Cosmologies}

It should first be noted that the Canadian colonial project has always relied on the disenfranchisement of Indigenous peoples from their territories which, in turn, eradicates senses of community. I aim both to situate traditional Anishnaabe understandings and protocols within the pre-colonial mind ${ }^{3}$ (Hill, 2012), and to examine the consequences of violent interruptions to these traditional understandings and protocols. Indigenous peoples across Turtle Island ${ }^{4}$ have always maintained protocols that negotiated how newcomers would be incorporated into society, which included the sharing practices of distinctive Indigenous knowledge, as well as members of one nation living in another nation's land. While the implications of forced relocation and urbanization cannot be underestimated, I intend to trace place and inheriting as situated ${ }^{5}$ realities. $^{2}$

Secondly, Anishnaabe spirituality varies from place to place. Multiple Anishnaabe territories across Turtle Island exist and therefore spiritual practices are differentiated in terms of the landscape of place (various clan systems, ceremonies, rituals specific to elements of that territory, etc.). As well, Anishnaabe spirituality may be differentiated in terms of how and why ceremonies are practised. The complex nature of this spirituality is emblematic of how place and the relationship with place are both particular and nuanced through Anishnaabeg communities. This paper will not explicate the nature of differences among these layers of Anishnaabe spirituality; rather, it refers to Anishnaabe spirituality as a function, which is central to our cosmologies.

Colonial mapping in Canada has attempted to sever the spiritual and material relationships between inhabitants of place. In this attempted severing, the understanding of place has been perverted into a resource-based relationship with land. Coulthard (2010) provides a crucial re-centring of place and its scope:

It is a profound misunderstanding to think of land or place as simply some material object of profound importance to Indigenous cultures (although it is this too); instead it ought to

\footnotetext{
${ }^{2}$ Anishnaabe refers to the nation of peoples; Anishnaabeg refers to the people belonging to this nation.

${ }^{3}$ The "pre-colonial” mind concerns the act of understanding Indigenous concepts and traditions in a non-reflexive frame, that is, not informed or reflected by and against colonialism.

${ }^{4}$ Turtle Island refers to the continent of North America. Many Anishnaabeg refer to Turtle Island when speaking of their homeland because of the sacred place the turtle holds in creation stories.

${ }^{5}$ I use the term situated in identifying localized knowledges (see Haraway, 1988).
} 
be understood as a field of relationships of things to each other. Place is a way of knowing, experiencing, and relating with the world - and these ways of knowing often guide forms of resistance to power relations that threaten to erase or destroy our senses of place. (p. 79)

The field of relationships that Coulthard (2010) refers to, I argue, is a mechanism of inheriting. Place, then, is the material and non-material space of inheriting. It is also reinforces the notion of how communities are structured: community is a network of tacit relationships anchored in particular geography and knowledge systems.

Place is both birth and inheritance. According to Anishnaabe beliefs, humans are of the land. The land is our first mother, and first woman (Simpson, 2011). She is not a myth, or a story. She is our history and our material, biological mother. Therefore we are of her. Our materiality, spirits, minds, and emotions are all interconnected and share a material connection to land. In this birth, we (and other beings) inherit throughout our lifetime. Place includes stories, histories, meaning, territory (land, waters, rocks, air), humans, non-humans, the spirit world, protocols, and governance systems (Johnston, 1987). It is the basis for our cosmology and how we relate within a society. When we bury our children's placentas in the earth, it is both a recognition and introduction of this new being to place. When we bury our people at the end of a lifetime, they return to the land and become part of the process of inheriting through their bodies and their spirits. All new beings carry the knowledge of beings before them. The relationship we have to place is also one that we have with ourselves. When place is altered, we are altered as current and future inheritors. If this altering is a form of disembodiment, what we can bestow is limited to what we have adapted against.

The spirit world inherits as well. It is the receiver of our prayers, offerings, and communication. For example, in the smudging ceremony(or simply, "smudging”), ${ }^{6}$ which involves the burning of sage as a purification cleansing ritual so as to cleanse the person's mind, spirit, body, and emotions of negative energy, we are asking the spirit world and the spirit of the sage itself to aid in our emotional, physical, spiritual, and mental cleansing. The sage that is burnt is materially cleansing these parts of ourselves. The spirit world is engaged in ceremony with us through the usage of sage, and correspondingly the spirit world can also affect us and other beings through dreams, signs, and ceremonies. This shared affectual relationship is both accommodated by place and embodied in place - the basis of which is reciprocity. For many Anishnaabeg, our spirituality is essentially tied to place as are the spirits of our ancestors (both human and non-human). We conduct ceremony for them, and they conduct ceremony for us. Place is a space of exchange, which invites the question: In the presence of a reciprocal and interdependent relationship, when place is altered, is the spirit world altered as well?

${ }^{6}$ Smudging is a purification ceremony Anishnaabeg have always practised, but is not limited to the Anishnaabe. It is also a common practice in some other Indigenous cultures. 
In order to begin to understand our spirituality, it is essential to examine how nonhumans are engaged within Anishnaabe societies. Firstly, non-humans are active agents who founded society (Benton-Benai, 2010). They are not separate from the political, the social, the private, or the public. Animals, the sky world, the water world, the plant world, the rocks, the spirit world - all pre-existed humankind (Benton-Benai, 2010). They are not species and elements reacting to instinct. Rather, these worlds represent sophisticated, functioning, selfgoverning societies. These societies have ethical structures, and inter-species treaties and agreements. Further, they possess the ability to interpret, understand, and implement. Human beings were the last to arrive on earth, according to our creation story (Benton-Benai, 2010). As founders, non-humans directly influence how humans organize themselves into a given society. The emergence and subsequent inclusion of human beings into society was negotiated through councils of non-human beings. For example, in one understanding of Anishnaabe clan systems, the Fish Clan represents the intellectuals, teachers, and scholars (Benton-Benai, 2010). The identification with this clan among humans was not merely based on the observation of fish traits. Rather, this relationship was determined by fish themselves — an agreement to regard human beings as kin, and vice-versa.

It follows that we as Anishnaabeg are extensions of the very land we walk upon, and therefore have an obligation to maintain communication with it. The nature of this obligation also cautions us that if we do not care for the land, we run the risk of losing who we are as Anishnaabeg. Smudging is one aspect of this communication and obligates us to use material elements of place for this exchange, and affirms the embodied relationship we have to place.

If we accept that as Anishnaabeg we are of the land, and that land is alive, then it follows that our thoughts, systems, and understandings of the world are essentially tied to place. It is not just a physical displacement that is risked through continued dispossession of lands: our ability to think, act, and govern also becomes compromised. Colonialism has disrupted our ability to communicate with place and has endangered agency amongst Indigenous peoples (Cajete, 2000). During the initial period of colonization of Indigenous territories on Turtle Island, Christianity and capitalism were fundamental in transforming our many places. Place was (and is) confronted with a form of diminutive agency wherein non-humans have been considered to be non-rational and non-spiritual, and by European estimation, so were we (Smith, 1999). Over time, through assimilationist tactics and violence, our own ability to act and converse with non-humans and other humans became compromised. The consequences of this extend beyond losing a form of Indigenous identity or worldview and how it is practised - it has resulted in a violation of land's intentionality.

Place and inheriting in relation to the spirit world can be understood through the story of how Nenaboozhoo created the spirit world. Storyteller Isaac Murdoch (2014) of Serpent River First Nation retells this story. Nenaboozhoo was born of a human woman whose father was the spirit of the western wind: 
International Journal of Child, Youth and Family Studies (2016) 7(1): 148-170

Nenaboozhoo noticed that all those spirits were just roaming endlessly in the sky, and thought, "I think I know what to do." Noticing that a turtle was pouting by a rock, Nenaboozhoo said, "Why don't you do me a favour, you're so beautiful and you're so gifted, why don't you bring me some nice beautiful stones from the edge of the lake 'cause I want to use them.” The turtle was mad because when Nenaboozhoo was creating the earth he didn't include turtle, so turtle was jealous and he felt left out. As the turtle was at the edge of the lake, Nenaboozhoo grabbed him and threw him far out into the lake. The turtle was very angry and swam to the bottom and sat right in the middle of the lake. When that turtle came up for air Nenaboozhoo shot his arrow at it, and of course that arrow hit that shell and when it did, startled turtle and all that mud that was on that turtle's back and tail flipped up into the sky. And they say it created Jibiiy Miikan, the sacred path in the afterlife that went from east to west.

The mud that was on turtle's back and tail had come from Nenaboozhoo's grandmother Nokomis's medicine that was all scattered at the bottom of the lake. It was her medicine that got flung right across the sky. Nenaboozhoo knew that, and said, "Here is a sacred trail and to finish this I'm going to make a place for those who departed.” Nenaboozhoo walked down the path that goes from east to west, and at the end he created the spirit world. They say he was there for a long time creating everything and he made it very beautiful, even more beautiful than the earth, they say. All of the rocks were gorgeous, the trees, the animals and their colours were absolutely pure. So that's how the spirit world came to the Anishinabe, and they say that when someone passes away, their spirits go through the eastern door, and they travel south and out the western door. And they say that his brother, the brother that was born as a black stone, wanted to look after that place up there. So Nenaboozhoo told his brother "I will send you there, and that will be your place to look after.” (p. 10)

Nenaboozhoo is part human and part spirit. He is regarded by Anishnaabeg as aiding in creation. Weaver's (1997) discussion on polycentrism among Indigenous communities is helpful in understanding the implications of the above story and the possibility of multiple spirit worlds. These multiple worlds are indicative of each cosmology as being universally held to local places. Each cosmology had a sacred right to its own existence and was to be respected by descendants of other cosmologies. This dynamic of respect and interdependence can be applied to the spirit world as well. In the story of Nenaboozhoo, we are told that he created the spirit world where the wandering spirits of the territory could be organized and continue to live, finding new purpose.

If we apply Weaver's (2007) claim that there are multiple cosmologies belonging to particular territories, then we must also consider that there are indeed multiple spirit worlds that are locatable and accessible through distinctive places and particular cosmological beliefs. A multiplicity of worlds does not preclude meaningful interaction or exchanges between them; 
International Journal of Child, Youth and Family Studies (2016) 7(1): 148-170

rather, multiple spirit worlds have their own beginnings and internal processes that are particular to territory or place.

Further to Weaver's (2007) point, the multiple points of centrism or spirit worlds would be created out of material places. For Nenaboozhoo, he used a turtle, the lake, mud from the bottom of the lake, and an arrow to create the spirit world. All of these elements are familiar and locatable for the Anishnaabeg. In addition, Nenaboozhoo's powers are born of both a human (his mother) and the Western wind (his father). This power manifested itself into a place where spirits (including those of humans) could go after experiencing death (walking through the western doorway).

Finally, the story of Nenaboozhoo tells us that after walking Jibiiy Miikan (the sacred path into the spirit world), rocks, waters, trees, plants, and animals are found within it. Therefore, there is a sacred relationship that human beings have with these companions of place during our time here, and they continue and translate into the western stage of life: death and beyond. The main contention of this reality is that spirit resides in the material bodies of all companions, including ourselves. Given that Nenaboozhoo tells us the spirit world is a direct consequence of the material and physical aspects of place, it must therefore also be true that the spirit world has the potential to be constantly affected by the circumstances and happenings of the material world. The beings of the spirit world can experience the feasts we hold for them in this world and the ceremonies we conduct for them, and they too give to us through ceremony, dreams, songs, art, shapeshifting, and so on. This fluid exchange is not without more dangerous impacts, those impacts being the ones that result outside of acts of gratitude, generosity, and calls for aid. The spirit world receives all that we offer and is affected by place continuously, not solely from one pure moment in its time of inception (Dei, 2000). Since colonization began, we have been witness to rampant destruction of place, and some of us have become contributors to this destruction. If we know our spirituality can be located on the earthly plane, to what extent can we now access the spiritual, given the damage to place amidst colonialism?

\section{Disembodiment}

The colonization of Indigenous places has corrupted, and continues to corrupt, the reciprocal relationship of bequeathing and inheriting between all worlds and their communities: spirit, animal, human, rock, sky, water, winged, and plant. Foreign religious influences have been particularly destructive to this inheriting process. The massive violations against Indigenous peoples and territories by Christian nations during the time of conquest without a sense of godly purpose would have been considered the epitome of savageness by these nations, to be sure. Furthermore, the conquering of peoples, places, and spirits was rationalized as a design of sacred obligations. The usage of Christian institutions and doctrine to facilitate the colonial imperative (wealth through dominion over land) was considered a marker of being civilized (Wilson, 2000) - even of divinity. Stephen Riggs, an Ohio-born missionary to the Sioux from 1837 to 1883, stated: 
International Journal of Child, Youth and Family Studies (2016) 7(1): 148-170

As tribes and nations the Indians must perish and live only as men! With this impression of the tendency of God's purposes as they are being developed year after year, I would labor to prepare them to fall in with Christian civilization that is destined to cover the earth. (Berkhofer, 1972, p. 7)

The export of Christian doctrine from Europe to the "New World" demonstrates that not only was Christianity abstracted from its original place, but that it was a Christian duty to Christianize non-Christian places. Christians are instructed to: "Go into all the world and proclaim the gospel to the whole creation. Whoever believes and is baptized will be saved, but whoever does not believe will be condemned.” (Mark 16:15-16, English Standard Version). The doctrines of Christianity are transportable because its divine nature is spiritual — and the spiritual is thought to be unconstrained by place. It is not only transportable, but valued as inherently good; as something that should be sought after and spread throughout the world. The implications for dispossession of Indigenous lands are not subtle. The reasoning for non-located spirituality serves to not only transform Indigenous lands into Christian ones, but to disconnect us from our cosmologies.

I do not contend that the many religious denominations of Christianity do not hold particular places as holy or sacred; Bethlehem and Jerusalem are just some of the places that are regarded in this way (Mazumdar \& Mazumdar, 2007). However, the transportable nature of these denominations is not commensurate with the cosmological view of Indigenous places. Deloria (2003) writes:

Just as the temporal world religions find a place for sacred sites, so spatial religions deal with the passage of time and the increasing complexity that it brings to human societies by attached stories to the sacred places ... The hazard that appears within the spatial conceptions of religion is the effect that missionary activity has on its integrity when it tries to leave its homeland. Can it leave the land of its nativity and embark on a program of world or continental conquest without losing its religious essence in favor of purely political or economic considerations? Are ceremonies restricted to particular places, and do they become useless in a foreign land? (p. 69)

Deloria (2003) questions not the validity of Christianity itself, but rather the efficacy of a religious system once it has been transported to a foreign land. So, if we can briefly suspend the context of colonialism or the violent effects that Christianity as a system has had on Indigenous communities, and question the stability of a substantive belief system outside of its sacred places, the effectiveness and purposefulness of this system is called into question. The stories inherent in Christian doctrine therefore become historical references to foreign places when distributed to unknown worlds.

The vastness of the "New World” was mistakenly perceived by European newcomers as an unpeopled wilderness, a virtual Garden of Eden. The categorization of Indigenous peoples as 
“sub-human” further legitimized the Europeans' view of the colonization of land and its inhabitants as progressive and necessary (Smith, 1999). Indigenous peoples and their spiritual lives were viewed as similar to the land itself - terra nullius. In a blog post examining the violence against missing and murdered Indigenous women, Sayers (2015) referenced this idea, claiming that the female Indigenous body is perceived by settler society as existing in a perpetual state of terra nullius. If we take this comparison and apply it to the spiritual lives of Indigenous peoples at the time of contact, they would be viewed in the same way as territory was - empty and ripe for spiritual fulfilment. This view was operationalized not only in mass-missionary operations during the settlement of Canada, but also in the forced conversions of Indigenous peoples in exchange for food, shelter, and education (Wilson, 2000). For example, industrial schools and day schools, which were in operation before and during the formalized residential school system, were afflicted with violence, forced labour, sexual and physical abuse, or — at the very least — negligence (Canadian Broadcasting Corporation, 2013).

The IRS system, which was funded by the federal government and overseen by various churches, ${ }^{7}$ isolated children from their families and communities. Attendance of Indigenous children at these schools from ages 4 to 16 was mandatory under law (Chansonneuve, 2005), and children were vulnerable to continued abuses for years on end in many cases. The effects of these schools still continue today in the intergenerational impacts on residential school survivors and their families (Chansonneuve, 2005).

The churches were empowered by the state to carry out a policy of aggressive assimilation under the Canadian government. The continued presence of distinctive peoples or "Indians" as defined under the law created fiduciary, and thus, economic, obligations of the state that were thought to impede both progress and further access to land. Former Superintendent of Indian Affairs, Duncan Campbell Scott, was empowered to oversee the IRS system. His objective was to acculturate Indigenous peoples, so that any uniquely held relationship to the land (legal or cosmological) would be dissolved. Scott stated:

I want to get rid of the Indian problem. I do not think as a matter of fact, that the country ought to continuously protect a class of people who are able to stand alone.... Our objective is to continue until there is not a single Indian in Canada that has not been absorbed into the body politic and there is no Indian question, and no Indian Department. (Titley, 2011, p. 50)

The policy of aggressive assimilation entrenched within the IRS system would only be considered successful if the targeted population of Indigenous children would continue to participate in a process of de-localized inheritance beyond the schools themselves. This would

\footnotetext{
${ }^{7}$ The churches empowered to oversee residential schools included Roman Catholic, Anglican, Methodist, Presbyterian, and United.
} 
include the erasure of a spiritual relationship to place. Within this process, the ability of Indigenous peoples to inherit is oriented not to place, but rather to a dislocated, normalized mimicry. Notes from the Legislative Assembly of the Province of Canada describe how the "Indian problem" is properly a lack of whiteness:

The chief obstacles to the advancement of the race are ... their ignorance or imperfect knowledge of the language, customs, and mode of traffic of the whites; and that feebleness of the reasoning powers, which is the necessary consequences of the entire absence of mental cultivation. (Canada, 1847, Appendix T)

The assimilation of Indigenous peoples by the state was a failure for many reasons, one of them being that ancient processes of inheriting that pre-existed contact could not be easily replaced by a mocked-up identity. Our inheritance extends beyond the transmission of knowledge as told in stories; it is the material extension of and reintegration of place. This is not a trivial process, and is a consequence of our very existence as human beings. Assimilation continues to be a failure of inheriting — a god-trick borne out of the arriving settlers' desire to create Indians in their own image.

Residential schools did not emerge solely out of the racist intent to "kill the Indian in the child" (Chansonneuve, 2005), or even to instil a core value system predicated on white Christian values. Attempts to assimilate Indigenous children during the IRS era have changed to other, less obvious forms than the pronounced removal of children from their places. Take, for example, the capitalistic approach to viewing land as a resource exploitable for profit, devoid of spiritual characteristics. Milloy (1999) argues that the teaching of industry, and specifically agriculture, was considered by churches running the residential schools to be essential to "breaking Aboriginal spirituality” (Milloy, 1999, p. 53). Teaching Indigenous children to tend crops and livestock fostered a different understanding of how they might relate to land. The residential school system not only introduced a counterintuitive misuse of place, but resulted in a violent severance of spiritual exchange between children and places.

This severing is highlighted in the following story, also retold by Isaac Murdoch (2014), about a young Anishnaabe boy from Serpent River, Ontario:

Now I'm going to tell you a little story. In the Spanish residential school, there was a young boy that died of chicken pox. They say he had lumps on his face and he passed away. So on Serpent River they took that small child and wrapped him in birch bark and they buried him at the old village site. In that old village, there's a big graveyard there, and they wrapped him up in birch bark and they put in him in a shallow grave. But the people in Spanish at the residential school said, "No, he was baptized we have full rights to that body, under god's authority, under someone's authority”. They went back to that old Indian burial site and they dug up his grave and they took it back to Spanish and put him in an unmarked grave and of course that's where the grave is now. The fact the 
International Journal of Child, Youth and Family Studies (2016) 7(1): 148-170

people from Spanish stole the body from the grave and put the body in another grave is not unique or strange, because they probably did that all the time. What makes this story unique is they actually documented everything that happened with the family, with the burial, with everything. The French person wrote what he saw down, he said, "When we arrived at the graveside the Anishnaabe were dancing at the grave" and they said 'that they were celebrating the life of the young person, and that they were dancing in circles around the grave'”.

On the grave, on top, they had made a little wigwam made out of birch bark and inside that wigwam they had placed food inside. On the west side of the grave they had a fire, and they said that they were cooking on the fire. The ritual of dancing around the grave would last for 10 to 15 minutes, then stop, they'd eat, tell stories then the dance would start again. So, when the residential school people went up to this grave and said, "We have to take this grave." the Anishnaabe said, "You can't bother the body because it's travelling, it’s going west, it's going home”. That's what he recorded them saying.

“The residential school people said, "We have no choice” and the Anishnaabe said, "If you bother it, maybe Nenaboozhoo will get mad at you”. Of course the French people from the residential school laughed, because they felt like they were the boss of everything I guess and at that time they probably really were. The residential school people, started to dig the grave, and again they recorded everything, and what they said was that when they started to dig the grave, the mother was crying at the bottom of the lake. At that gravesite it goes down and there's a lake at the bottom. The Anishnaabe said that the residential school people couldn't understand why she was crying so hard because her son was going to go to heaven and not hell. So of course they took the body and they unrolled the birch bark, and what they found inside the birch bark were supplies. They found dried meat, they found dried berries, they found a little knife, they found a candle, they found a little axe, and moccasins and the boy was painted red. The residential school people had to clean the boy up, they couldn't just bury him like that and so they actually took the body back to Spanish and they washed the paint off the boy and the put in him a suit of some sort, and they put him in an unmarked grave, and the parents never knew where he was buried. When you listen to that story, it's a very tragic story right? The tragedy is not just the fact that the boy was stolen from our gravesite, but our way of life, how we looked at the spirit world, was also stolen too. Because now all those little boys, obviously their family believed that there was a spirit road that went from east to west, that was taken away from them. (p. 11-12).

The burial rites identified in the story above are anchored in the material and create a point of access from one world to another. The material belongings that the young boy would take with him in his westward walk are not reducible to symbolic representations. This violation, not only in undoing the rites of this young boy in his death, but in his entrance into another 
world, is a place-based experience. From the removal of the birch bark to the denial of sustenance to him, all participants in this process are deprived of their ability to be agent. This deprivation, couched in a salvation narrative (i.e., that the boy is worthy of a Christian burial) is reflective of the arrogance inherent in assimilationist practices. The Christian rites that were imposed are a form of post-mortem acculturation, an act to de-situate this young boy's materiality and immateriality, thus interrupting the ability of the spirit world to inherit him. In one sense, the spirit world itself experiences its own strain. How do elements of the spirit world accommodate these injustices, similar to the ones identified in this story? The spiritual lives of Indigenous peoples and places were violated during the residential school system era. The hundreds of thousands of stolen children from their families were also stolen from their place of communication with the spirit world.

Arthur Ron McKay, a survivor of Sandy Bay Indian Residential School, spoke of his experience in becoming an altar boy to "try their way”. He recounts:

That's how I lost all my ... beliefs, traditional things that I knew from my grandfather, the songs that he tried to show me because I knew some songs before I left for school and I forgot all about those songs, traditional songs, Sun Dance songs, even when I was younger, that young I knew and I knew how to do all the little things that the medicines, he used to pick. By this time then I was going back on the last years, I forgot all about those. (Truth and Reconciliation Commission of Canada, 2015, p. 88)

Stories like Arthur Ron McKay's are not uncommon amongst residential school survivors. Many survivors have been able to reconnect to their traditions, but many have not. The place-based role to bequeath and subsequently inherit within families was also stolen, at least temporarily. This fractured dynamic is still present today, as exemplified in the intergenerational effects on survivors and their families produced out of residential school trauma (Chansonneuve, 2005). Given the efforts under colonization to disembody the spiritual lives of Indigenous places for the purposes of state-sponsored assimilation, it is crucial to examine the consequences of these impacts.

\section{Playing Indian?}

In the article from which the excerpt below is taken, Winnipeg Free Press journalist Mary Agnes Welch (2012) details historical injustices Indigenous people have been forced to endure by the state. It is through this account that she is able to reconcile the impatience she regularly felt when attending events that were opened with a time-consuming traditional smudging ceremony:

The aboriginal ceremonies where sage or another traditional medicine is burned in a little bowl and passed around so everyone can waft the smoke over themselves ... It's for purification, and it's a solemn, slow, peaceful, pungent ritual.... If you're a self-important 
journalist juggling two other stories who only plugged the parking meter for an hour, the whole thing can make you antsy, especially if the smudge is prolonged by prayers in Cree or Ojibwa by an elder and a drum circle song or two. (Welch, 2012)

In Welch’s (2012) original estimation, smudging is a time-consuming and annoying practice. She convinces herself (and presumably, her primarily non-Indigenous audience) that the smudging ceremony should at least be tolerated, given that it is a practice that should not have survived at all. In obliging this type of practice, Welch (2012) concludes: "So, now that I've learned some of the history and how a culture survived against government policies designed to overwhelm it, I'll put a little extra money in the meter, settle in for some drumming and the smudge and say miigwetch ${ }^{8}$." (Welch, 2012). In this case, ceremony is analogous to Indigenous peoples themselves — how can it/they still be practised/alive? What is most significant about her statement is the recognition of Indigenous ceremony as central to functions of Indigenous governance and politics, while paradoxically insignificant to any matters of importance. Welch (2012) echoes the frustrations of settler society more generally; Indigenous ceremonial practices are viewed as inferior in their design and function, and yet are an obligatory part of achieving socalled multicultural tolerance.

In our current times, place does not exist in purity. It may never have, but certainly in pre-contact times, place was closer to how Anishnaabe stories portray its original design, and existed as a self-determining agent. This does not mean a pre-contact state is equal to a pure or innocent state. Rather, place was powerfully engaged with the spirit world, and we as humans were situated in a place of reverence towards this power as opposed to being predatory gatherers of it (Johnston, 1987). It is important not to oversimplify, or imagine that Anishnaabe peoples (and Indigenous peoples generally) were exempt from dissent or irresponsibility. There were wartimes, corruption, and immoral acts, and there are many stories in many nations that describe such events. However, violations against place were considered punishable, not something to be celebrated as progress. Borrows (1996) re-tells the story of Nanabush (Nenaboozhoo), in which the Deer Nation denies the Anishnaabe access to them for hunting purposes. The Anishnaabe had violated a former agreement with the Deer Nation by disrespecting the bodies of the deer, thus acting without respect or integrity. For Anishnaabeg, our intellectual capacities were operationalized differently because of historic agreements between humans and non-humans, and thus the intrinsic tie to the place and the spiritual life of it.

It is important not to criticize or pathologize the reasons why some Anishnaabeg (and other Indigenous peoples) may not practise traditional ceremonies in this context. Rather, it is critical to understand the function that ceremonies continue to have in relation to assimilation. From a colonial perspective, ceremony continues to be regarded as a polarizing practice.

\footnotetext{
8 "Miigwetch" is an Anishnaabe term and translates into an expression of gratitude or, "thank you".
} 
Indigenous ceremonies were banned by an amendment to the Indian Act in 1884 (Canada, 1884). For almost three-quarters of a century, ceremonies were forced underground, to be practised quietly until this ban was lifted in 1951 (Canada, 1951). It was believed by the Canadian government that these ceremonies were uncivilized and pagan (Milloy, 1999). Yet, Canada found these "uncivilized" rituals to be so threatening that it forbade them. Despite the decriminalization of ceremony, which ostensibly might appear to encourage restoration of Indigenous traditional practices, I argue that the allowance of place-based ceremony was strategic in institutionalizing assimilation further as evidenced by other amendments to the Indian Act made at that time. For example, First Nations communities were granted permission to take the federal government to court over land disputes in 1951 (Canada, 1951). Subsequently, the federal government created the specific and comprehensive land claims process, wherein Indigenous communities could enter into negotiations with federal and provincial governments to resolve treaty violations or unsettled land so long as they agreed to the extinguishment of Aboriginal title (Alfred, 2009). The ability to inherit amongst Indigenous peoples was redefined under a neoliberal rights-based system. This re-identification was, and is, a process of diluting place-based obligations as cultural rights accorded by the state.

Places that were once regarded as sacred became paved over or private property. Indigenous peoples had been relocated to reserves, and the traditional territories that we once had access to were, and are, increasingly privatized and environmentally corrupted. How has ceremony transitioned and adapted to this new reality of place? Oftentimes, Indigenous ceremonial practices are thought of as both a decolonizing act as well as an indigenizing one. That is, by participating in our ceremonies we are becoming more connected to our traditional protocols as Indigenous peoples, which consequently makes us less colonized. This reembodiment does not exist in a vacuum. As Simpson (2004) argues, Indigenous knowledge is increasingly becoming a provocative point of accessibility for settler governments and corporations to more expediently gain access to Indigenous lands and resources. For instance, the study of Traditional Ecological Knowledge (TEK) is premised on the notion that Indigenous peoples, globally, have a distinctive and intimate relationship with the knowledge of Indigenous territories as it relates to sustainability (McGregor, 2004). Simpson (2004) cautions against the increasing trend of institutionalization of TEK. She warns that while the recognition of the value inherent in Indigenous knowledge systems can be productive in terms of sustainability, this recognition also risks making TEK vulnerable to the resource-based desires of the state (Simpson, 2004).

Ceremony in this sense, represents just another function of multiculturalism, a cultural right to be allowed by the state rather than serving as the basis for independent societies. It is regarded as something interesting, mystical, and by some accounts, akin to witchcraft (Federici, 2006). As Welch (2012) demonstrates, ceremony is something that can either be appreciated or detested, but it is not considered threatening to state power. In another sense, if we as Indigenous peoples practise ceremony in its most meaningful places, in the most reverent way, and act to 
implement the consequent messages sent from place, we would surely be regarded as terrorists by the state. When Anishnaabeg participate in ceremony at its most powerful (i.e., allowing place to communicate to us), we are acting against the settler state agenda of silencing or extracting place. Ceremony in this way would emphasize our obligation to protect not only what is left of our cosmological manifestations, but try to restore place to its original place of dignity. This type of restoration in the eyes of settler states is tantamount to a threat against the political, economic, and sovereign will of the nation.

The inviting of Indigenous ceremonial practices into statist spaces extends beyond a socalled agenda of tolerance. These types of invitations represent a working towards assimilated, Indigenous communities that reflect statist ideals. Anderson (2013) provides an analysis of Indigenous peoples citing Hall's (1993) discussion on identity that is helpful in this discussion; Anderson claims that Hall's use of "essence" and "becoming” is helpful in understanding the complexities of Indigenous identity in urban centres. Essence in this context refers to the common "cultural codes" and "frames of reference" which inform cultural identities. Hall (1993) also argues that these essences are in a state of "becoming”; cultural identities do not exist in a fixed past, but are sensitive to an ever-changing present and future (Anderson, 2013, p. 49). Thus, identity is constantly emerging amidst common and historical categories. Anderson (2013) finds these two seeming paradoxes to be helpful in his discussion on identity amongst Indigenous urban peoples: the authenticity of an Indigenous person should not be measured in terms of an ostensibly more authentic "reserve" identity. That is, the identity of Indigenous peoples living on lands reserved solely for "Indians" under the law should not be considered more authentic than those Indigenous peoples living in urban centres. While this argument may be appropriate in explicating how Indigenous identities are shaped amidst urbanization and colonial processes of ascribing Indigenous membership, I find this same reasoning raises problems when applied to Indigenous ceremonies practised in colonial contexts.

Take for example, the idea that Indigenous ceremony may be viewed as potentially transformative in terms of colonial practices. That is, the practice of Indigenous ceremonies amidst colonial operations might combat the potentially destructive effects of colonialism. Similar to Simpson's (2004) contention about TEK, I argue rather that the institutionalization of ceremony at state and corporate levels is an exercise in the attempted disembodiment of ceremony from place.

In 2007, former premier Gordon Campbell was instrumental in the British Columbia Treaty Process, a comprehensive land claims process that would ultimately extinguish Aboriginal title over Indigenous lands. Campbell was pictured in the Vancouver Sun newspaper, alongside former Governor of California Arnold Schwarzenegger, blanketed with "ceremonial First Nations blankets” at an economic summit in Vancouver (Vancouver Sun, 2011; Canadian Broadcasting Corporation, 2007). In Ottawa, Indigenous ceremonial practice with government bureaucrats has become commonplace. In 2012, at a summit aimed towards "resetting the relationship", National Chief Shawn Atleo of the Assembly of First Nations and Prime Minister 
Harper were being smudged together by an Elder. Prime Minister Harper stated that several Aboriginal uprisings led to the need to reset the relationship between Aboriginal peoples and the state, and this would include bringing communities fully into Canada's economy (Postmedia News, 2012). Less than a year later, the Idle No More movement in Canada arose, an Indigenous movement that critiqued the corporate and anti-environmental processes that Prime Minister Harper planned to employ to bring Indigenous communities and lands into Canada's economy.

Mohawk scholar Taiaiake Alfred (1999) writes on the problem of co-option: "The complexity of indigenous-state relations gives agents of the state many opportunities and mechanisms to move Indigenous leaders away from their communities, politically and ideologically, and towards the state.” (p. 74) I argue that the co-option of Indigenous ceremonies is purposeful, and designed to construct a more conciliatory form of access to Indigenous lands. From an historical conflation with witchcraft to a more contemporary association to access, the practice of Indigenous ceremonies in colonial settings symbolizes a permissiveness that was never granted.

I term this trend of state-legitimated ceremony as "boardroom smudging”. Boardroom smudging is emblematic of tolerance of Indigenous ceremony versus meaningful engagement in ceremony's intentions. We know that ceremony is place-based, and is a method of exchange between humans, non-humans, and the spirit world. The act of ceremony outside of traditional places (for example, in colonial spaces such as boardrooms), can still be meaningful, but could also be a measure of disembodiment (the corruption of the spiritual life of place). This disembodiment is further intensified when it is used for purposes counter to spiritual processes. When the state engages in Indigenous ceremonies with Indigenous peoples to gain further concessions from place (e.g., extracting resources), both place and ceremony become increasingly damaged. This not only compromises meaningful communication with the spirit world (which is affected by the exercises of place), but also can authorize false notions of spiritprompted engagement and subsequent blessings.

Is there a complicity in engaging our ceremonies in neoliberal efforts to illegally dispossess us of our lands? Does smudging before entering into a land claim negotiation or an oil sands development venture decrease impacts to place, or does it fulfill the colonial fantasies of terra nullius? Aldred's (2000) discussion on authenticity is helpful here. Her commentary on the interaction of Vizenor's (1999) “nostalgia” (non-Indigenous peoples longing to be a part of an Indigenous authentic spirituality) and Deloria’s (1998) assertion that authenticity is necessary to tie Indigenous peoples to a material place, serves to provide a critical analysis on the emergence of new-ageism and "playing Indian”. Perhaps this notion is cloaked in assimilation when practised at a state level, wherein Indigenous ceremonies are disguised as tropes of diversity. While Aldred's (2000) discussion concerns the occurrence of non-Indigenous peoples "playing Indian”, I question the potential of Indigenous ceremonies themselves to become vulnerable to this notion of “playing Indian”. Indigenous ceremonies carry an inherent ability to effect change. While I agree that our ceremonies do not rely on (and can certainly resist) colonial efforts, I 
would argue that the dislocation of ceremony materially from place could produce a transmogrification of ceremony, therefore resulting in a contravention of place's intentionality.

Does this use (or misuse) of ceremony subscribe to the ever-emerging politics of adaptability where we, as Indigenous peoples, are aiding in the design of a space of dispossession? The many traditional Indigenous creation stories throughout the world speak to our locatable and material arrival out of place itself. It is dangerous to assume that our most sacred and traditional histories, stories, and teachings adapt into a state of natural reveal amidst violence, as Hall (1993) might argue. That is, because place has adjusted or transformed through colonial force, the so-called inevitability of this forced relationship may be viewed as naturally adaptive. To practise our ceremonies amidst constraints produced out of colonialism, while understandable and even necessary to some extent, should not be confused with an evolving state of adaptability or unencumbered resilience. As we can see from the story of Nenaboozhoo, the inhabitants of the spirit world and their method of communication with human beings and other non-humans are intrinsically tied to the elements of place. This teaching, and the many others from Indigenous places around the world, are at risk of becoming transformed themselves, and risk a reflexive relationship with colonialism rather than place.

There is no question that ceremony can be powerful wherever it is practised. It is also understood that beneath concrete lies dirt, rocks, and other original inhabitants. The assertion that place is therefore as dignified and powerful as it can be (underneath department stores and gas stations) is problematic. For instance, the assertion that Anishnaabe ceremonies are so powerful that they can withstand the counter-cosmological transformation of place implies an acceptance of this violence. The evacuation of our spiritual, material relationships with land serve the colonial fantasies of who we are supposed to be: something interesting to watch, something that does not impact expediency.

Adaptability is a distraction. The more we adapt, the more we distract from place and what we "become"; that is, our essence as in a state of reveal against external forces (i.e., colonialism). In turn, as humans we are at risk of allowing our ways to become permissive in the continued colonial transformation of place. While this assertion may be comforting to those of us who can no longer access those places to practise ceremony, it is not true resolve; rather, it is resignation to a forced adaptation, not the natural ability of communities to reveal themselves amidst external forces. Therefore, it is not that our ceremonies are not strong enough to adapt and still wield change amidst concrete, rather it is they should not be taken for granted as natural in the colonial transformation of place.

When we engage ceremony in the state’s agenda, are we then “playing Indian”? Perhaps we are producing an inheritable nostalgia for place that Vizenor (1999) references, a nostalgia that is borne out of a disembodied sacredness. This is exactly the kind of "Aboriginal” that Canada wishes us to be, and has been training us to be since the introduction of the fur trade, residential schools, and the mall. If we play Indian, Indigenous communities’ place becomes a 
International Journal of Child, Youth and Family Studies (2016) 7(1): 148-170

function of commodification, and ceremony risks becoming bequeathed as a naturalized metaphor of this nostalgia.

\section{Conclusion}

As Cindy Blackstock (2011) notes, there are more Indigenous children currently in the child welfare system than were in IRS during the height of the residential school system. As of 2013, almost $15 \%$ of the national population of children in care (or approximately 27,000 children) are Aboriginal (Assembly of First Nations, 2013). As discussions surrounding how to make this system more equitable and culturally appropriate for Indigenous children and their families occur, it is imperative to consider the impacts on Indigenous identities that are material, spiritual, and tied to territory.

Almost $60 \%$ of the national Aboriginal population resides in urban areas, and this proportion will no doubt continue to increase (Statistics Canada, 2011). This trend prompts the need for further discussion in terms of how our cosmologies and their ties to places are considered: Are these ties real or an abstracted cultural construction? Continued material productions of colonialism that are reflective of an evacuation of Indigenous cosmologies from place might produce the conditions for continued assimilation rather than the renewal of the spiritual lives of place's now-cemented constituents. What do we inherit for our families and from places?

The story of Nenaboozhoo creating the spirit world not only produces a belief system, or basis for ideology. When understood with the remembrance that Anishnaabeg are extensions of the land, place is also a function of inheriting. This process of inheriting is dependent on locatable places in its transmission. The introduction of a dislocated religious system was damaging to this process of inheriting. The spiritual lives of the inhabitants of place were the target of severing in order to transform and redefine place itself as empty and spiritually void so as to convert elements of place to both colonial and Christian constructions. This disembodiment served to not only create wealth amongst Christian nations, but suppressed communicative, relational exchange between the original inhabitants of place.

The IRS system was particularly violent in physically and spiritually severing children from their relationship with place in order to impose an alternative, Christianity-oriented, resource-based history with place. Inheriting amidst the perverse collaboration between church and state was an exercise in transposition — the hopeful (and ultimately failed) inheritability of an assimilated identity. Despite the damage done to place, ceremony is powerful; it too has the ability to transform. Our ceremonies are sacred descendants of place; colonialism is a descendent of nowhere. It is counterproductive to coalesce these contradictory belief systems. Embodied, locatable spirit worlds are dependent on elements of place. If elements of place are the object of state-oriented extractive and de-spiriting processes, meaningful ceremony will always be constrained. Boardroom smudging in these contexts can be described as a subdued 
communication with the spirit world that contributes to constructed, state-favoured Indigenous communities. The forced colonization of peoples and lands does not produce a natural, evolving reveal amongst inhabitants of place. This would conjure a fallacy of adaptability wherein colonialism is validated as natural and unavoidable, like the changing of the seasons. The danger lies in producing (not revealing) permissive societies that are not determined by place's intentions, but rather are motivated to help solve the state’s “Indian problem”.

Residential schools maintained, and urban spaces continue to maintain, a dynamic of severing with respect to Indigenous ceremonial practices. In the former they were denied, and in the latter they are invited. And yet, in both circumstances, Indigenous ceremonial practices are devalued; they are de-situated, disembodied, and removed from place. 
International Journal of Child, Youth and Family Studies (2016) 7(1): 148-170

\section{References}

Aldred, L. (2000). Plastic shamans and astroturf sun dances: New Age commercialization of Native American spirituality. The American Indian Quarterly, 24(3), 329-352.

Alfred, T. (1999). Peace, power, righteousness. Toronto, ON: Oxford University Press.

Alfred, T. (2009). Colonialism and state dependency. Journal of Aboriginal Health, 5(2), 42-60.

Anderson, C. (2013). Urban aboriginality as a distinctive identity, in twelve parts. In E. Peters \& C. Anderson (Eds.), Indigenous in the city: Contemporary identities and cultural innovation (pp. 46-68). Vancouver, BC: UBC Press.

Assembly of First Nations. (2013, October). Fact sheet - Child welfare. Retrieved from http://www.afn.ca/uploads/files/13-02-23_fact_sheet_-_child_welfare_updated_fe.pdf

Benton-Benai, E. (2010). The Mishomis book: The voice of the Ojibway. Minneapolis, MN: University of Minnesota Press.

Berkhofer, R. F. (1972). Salvation and the savage: An analysis of Protestant missions and American Indian response, 1787 - 1862. Lexington, KY: University of Kentucky Press.

Blackstock, C. (2011, February). Reconciliation means not saying sorry twice: How inequities in federal government child welfare funding, and benefit, on reserves drives First Nations children into foster care. Submission to the Standing Committee on the Status of Women, Ottawa, ON.

Borrows, J. (1996). With or without you: First Nations law in Canada. McGill Law Journal, 41, 629-665.

Cajete, G. (2000). Native science: Natural laws of interdependence. Sante Fe, NM: Clear Light.

Canada. (1847). Appendix to the sixth volume of the journals of the Legislative Assembly of the Province of Canada. [Appendix T]. Retrieved from http://eco.canadiana.ca/view/oocihm.9_00955_6_1/3?r=0\&s=1

Canada. (1884). An Act further to amend The Indian Act, 1880, S.C. 1884 (47 Vict.), c. 27, s. 3.

Canada. (1951). The Indian Act. Collections Canada.

Canadian Broadcasting Corporation. (2007, May 31). Schwarzenegger, Campbell formalize green agreement. Retrieved from http://www.cbc.ca/news/canada/britishcolumbia/schwarzenegger-campbell-formalize-green-agreement-1.656211 
International Journal of Child, Youth and Family Studies (2016) 7(1): 148-170

Canadian Broadcasting Corporation. (2013, May 23). Survivors of day schools share stories of abuse, pain. Retrieved from http://www.cbc.ca/news/canada/manitoba/survivors-of-day$\underline{\text { schools-share-stories-of-abuse-pain-1.1348955 }}$

Chansonneuve, D. (2005). Reclaiming connections: Understanding residential school trauma among Aboriginal people [Resource manual]. Ottawa, ON: Aboriginal Healing Foundation.

Coulthard, G. S. (2007). Subjects of empire: Indigenous Peoples and the 'politics of recognition' in Canada. Contemporary Political Theory, 6, 437-460.

Coulthard, G. S. (2010). Place against empire: Understanding Indigenous anti-colonialism. Affinities: A Journal of Radical Theory, Culture, and Action, 4(2), 79-83.

Dei, G. J. S. (2000). Rethinking the role of Indigenous knowledge in the academy. International Journal of Inclusive Education, 4(2), 111-132.

Deloria, P. J. (1998). Playing Indian. New Haven, CT: Yale University Press.

Deloria, V., Jr. (2003). God is red: A Native view of religion. Golden, CO: Fulcrum.

Federici, S. (2006). Caliban and the witch: Women, the body and primitive accumulation. New York, NY: Autonomedia.

Hall, S. (1993). Cultural identity and diaspora. In P. Williams \& L. Chrisman (Eds.), Colonial discourse and postcolonial theory: A reader (pp. 222-237). New York, NY: Harvester Wheatsheaf.

Haraway, D. (1988). Situated knowledges: The science question in feminism and the privilege of partial perspective. Feminist Studies, 14 (3), 575-599.

Hill, S. (2012, March 26). The John Mohawk memorial address. Given at the Storyteller's Conference, SUNY, Buffalo, NY.

Johnston, B. (1987). Ojibway heritage. Toronto: McClelland \& Stewart.

Mazumdar, S. [Shampa], \& Mazumdar, S. [Sanjoy]. (2004). Religion and place attachment: A study of sacred places. Journal of Environmental Psychology, 24(3), 385-397.

McGregor, D. (2004). Coming full circle: Indigenous knowledge, environment, and our future. The American Indian Quarterly, 28 (3\&4), 385-410.

Milloy, J. (1999). A national crime: The Canadian government and the residential schools system. Winnipeg, MB: University of Manitoba Press.

Minnesota Historical Society. (1973). The Ojibwe People. Retrieved from http://www.historicfortsnelling.org/history/american-indians/ojibwe-people 
International Journal of Child, Youth and Family Studies (2016) 7(1): 148-170

Murdoch, I. (2014, February). The trail of Nenaboozhoo: All the gifts he left us. Presented at a conference hosted by the Ojibwe Cultural Foundation, Sudbury, ON.

Postmedia News. (2012, January 24). After ‘aboriginal uprising’ warning, Stephen Harper says time has come to 'reset the relationship'. The National Post. Retrieved from http://news.nationalpost.com/news/canada/stephen-harper-pledges-to-reset-the-relationshipafter-aboriginal-uprising-warning

Sayers, N. (2015, March). Our bodies are not terra nullius. Kwe Today: Fierce Indigenous Feminism. Retrieved from http://kwetoday.com/2015/03/20/our-bodies-are-not-terra$\underline{\text { nullius/ }}$

Simpson, L. (2004). Anticolonial strategies for the recovery and maintenance of Indigenous knowledge. The American Indian Quarterly, 28(3\&4): 373-384.

Simpson, L. (2011). Dancing on our turtle's back: Stories of Nishnaabeg re-creation, resurgence, and a new emergence. Winnipeg, MB: Arbeiter Ring.

Smith, L. T. (1999). Decolonizing methodologies: Research and Indigenous Peoples. New York, NY: Zed Books.

Statistics Canada. (2011). Aboriginal Peoples in Canada: First Nations People, Métis and Inuit, National Household Survey. Retrieved from https://www12.statcan.gc.ca/nhs-enm/2011/assa/99-011-x/99-011-x2011001-eng.cfm

Titley, B. (2011). A narrow vision: Duncan Campbell Scott and the administration of Indian Affairs in Canada. Vancouver, BC: UBC Press.

Truth and Reconciliation Commission of Canada. (2015). The Survivors Speak. Ottawa, ON: Library and Archives Canada Cataloguing in Publication.

Vancouver Sun. (2011, May 17). Photos: 20 moments with Arnold Schwarzenegger [3rd photograph]. Retrieved from http://www.vancouversun.com/Photos+awkward+moments+with+Arnold+Schwarzenegger/ 4804499/story.html

Vizenor, G. (1999). Manifest manners: Narratives on postIndian survivance. Lincoln, NE: University of Nebraska Press.

Vizenor, G. (2008). Survivance: Narratives of Native presence. Lincoln, NE: University of Nebraska Press.

Weaver, J. (1997). That the people might live: Native American literatures and Native American community. New York, NY: Oxford University Press. 
International Journal of Child, Youth and Family Studies (2016) 7(1): 148-170

Welch, M. A. (2012, August 23). Learning to love the smudge. Winnipeg Free Press. Retrieved from http://www.winnipegfreepress.com/local/learning-to-love-the-smudge234935121.html

Wilson, J. (2000). The Earth shall weep: A history of Native America. New York, NY: Grove Press. 